\title{
Control of Fungal Diseases and Increase in Yields of a Cultivated Jujube Fruit (Zizyphus jujuba Miller var. inermis Rehder) Orchard by Employing Lysobacter antibioticus HS124
}

\author{
Jun-Hyeok Kwon ${ }^{1}$, Sang-Jae Won ${ }^{1}$, Jae-Hyun Moon ${ }^{1}$, Chul-Woo Kim ${ }^{2}$ and \\ Young-Sang Ahn 1,*(D) \\ 1 Department of Forest Resources, College of Agriculture and Life Sciences, Chonnam National University, \\ Gwangju 61186, Korea; wg6102@naver.com (J.-H.K.); lazyno@naver.com (S.-J.W.); \\ mjh132577@naver.com (J.-H.M.) \\ 2 Division of Special-purpose Trees, National Institute of Forest Science, Suwon 16631, Korea; \\ futuretree@korea.kr \\ * Correspondence: ysahn@jnu.ac.kr; Tel.: +82-62-530-2081
}

Received: 7 November 2019; Accepted: 13 December 2019; Published: 15 December 2019

\begin{abstract}
The objective of this study is to investigate the inhibitory effects of Lysobacter antibioticus HS124 on fungal phytopathogens causing gray mold rot, stem rot, and anthracnose. Another objective of this study is to promote the yield of fruit in jujube farms. L. antibioticus HS124 produces chitinase, a lytic enzyme with the potential to reduce mycelial growth of fungal phytopathogens involving hyphal alterations with swelling and bulbous structures, by 20.6 to $27.3 \%$. Inoculation with L. antibioticus HS124 decreased the appearance of fungal diseases in jujube farms and increased the fruit yield by decreasing fruit wilting and dropping. In addition, L. antibioticus HS124 produced the phytohormone auxin to promote vegetative growth, thereby increasing the fruit size. The yield of jujube fruits after L. antibioticus HS124 inoculation was increased by $6284.67 \mathrm{~g} / \mathrm{branch}$, which was 2.9-fold higher than that of the control. Auxin also stimulated fine root development and nutrient uptake in jujube trees. The concentrations of minerals, such as $\mathrm{K}, \mathrm{Ca}, \mathrm{Mg}$, and $\mathrm{P}$ in jujube fruits after L. antibioticus HS124 inoculation were significantly increased (1.4- to 2.0-fold greater than the concentrations in the control). These results revealed that L. antibioticus HS124 could not only control fungal diseases but also promote fruit yield in jujube farms.
\end{abstract}

Keywords: auxin; biocontrol; chitinase; fruit; fungal pathogen; jujube; Lysobacter antibioticus HS124; mineral concentration; production; Rhamnaceae

\section{Introduction}

Jujube (Zizyphus jujuba Miller var. inermis Rehder) is an elliptical or spherical-shaped fruit [1]. Approximately 170 species of jujube have been cultivated in China over the past 5000 years [1,2]. They are mainly cultivated in central and southern China and southern and eastern Europe where the climate is warm [3]. Jujube fruit is mostly consumed fresh. Its dried form is also consumed in various food products, such as bread, cake, candy, powder, and juice [4]. Jujube fruit is rich in fiber, minerals, phenolic compounds, and vitamins $[1,5]$. It can strengthen the cardiovascular system with its antioxidant capacity [6,7]. Eating one jujube fruit per day provides an adult with the dose of vitamins B and C recommended by the Food and Agriculture Organization of the United Nations (FAO)/World Health Organization (WHO) $[1,8]$. In addition, jujube seeds are known to contain saponins with pharmacological properties, such as antibacterial, insecticidal, anti-inflammatory, 
and immunity-enhancing activities $[9,10]$. In ancient China and Korea, jujube fruit was commonly used for health promotion and as a medicinal ingredient [10-13].

A high incidence of fruit fungal pathogens has been reported in intensive cultivation of jujube because of its high sugar content of approximately 5.4 to $10.5 \mathrm{~g} / 100 \mathrm{~g}$ and its high moisture content of over $80 \%[1,14]$. Fungal diseases in jujube fruits and trees include gray mold rot, stem rot, and anthracnose [15-18], which can reduce jujube production. Fungi and spores are mainly present in the soil and atmosphere. Rain, increases the atmospheric humidity, resulting in the cracking of jujube fruits. Thus, the interior part of the jujube is exposed to the outer environment where fungi and spores are present. Generally, it is difficult to control fungal diseases and fungicides can be used to control the fungal diseases in jujube farms $[19,20]$. However, the continuous use of fungicides results in an increased number of fungi with acquired resistance. Fungicide-resistant fungi require higher doses and increased fungicidal application frequency, eventually necessitating the development of new fungicides [20]. Although intensive farming methods ensure high yields and quality, they also require the use of excessive chemicals, such as fungicides, pesticides, and fertilizers [19]. Excessive use of chemicals can lead to environmental pollution, such as the eutrophication of water quality and salt accumulation in the soil [21], the destruction of soil microorganisms, and the inhibition of plant growth [22,23]. Recently, increased focus has been directed toward environmentally friendly practices in fruit cultivation systems. However, the cultivation of fruit tree orchards still suffers from fungal diseases because of the lack of knowledge regarding biological control methods.

Recent changes in awareness about the environment and changes in consumer trends favoring environmentally friendly crop products have prompted a demand to transform the existing farming methods [24,25]. Among various other eco-friendly cultivation methods, environmentally friendly cultivation methods that employ biological control by using microorganisms can promote crop production. Thus, they are gaining popularity because of their high potential value [25-28]. Plant growth promoting rhizobacteria (PGPR) play a significant role in reduction of infection by plant pathogenic fungi leading to be a promising alternative to control plant diseases. PGPR are known to produce lytic enzymes, preventing infection by fungal diseases [27-30]. However, the biocontrol efficacy of PGPR on diseases associated with jujube fruit is not clearly investigated. PGPR provide plants with phytohormones [24,31], especially auxin, which can loosen the cell wall of root tissue cells, allowing cells to absorb additional nutrients, thereby promoting the growth of root hair and lateral roots $[24,25,27,28,31,32]$. In addition, auxin helps establish symbiosis with rhizobia or mycorrhiza and facilitates the uptake of nutrients from soils, promoting plant production [24,25,27,28,31,32]. In particular, after the flower is fertilized, auxin acts on the division and expansion of cells, promoting vegetative growth and increasing fruit size and yield [31,33,34]. Lysobacter species are isolated from rhizosphere soil. Genus Lysobacter is famous for their positive effects on plant health [30,35]. Lysobacter antibioticus strains can produce a variety of bioactive compounds, including lytic enzymes and antimicrobial compounds, that can effectively inhibit the growth of phytopathogenic fungi [30]. However, the effects of bioenhancers derived from L. antibioticus strains on the production and nutrient uptake in fruit trees remain poorly understood.

Fruit trees have been studied with respect to many bacterial species that can act as PGPR. These bacterial species have been reported to successfully provide biological control of diseases and can also improve fruit production. However, there are only a few studies on the simultaneous use of PGPR for the biological control of disease and the promotion of fruit production [26,36]. Currently, the increasing demand for fruit tree production, along with a significant reduction in the use of synthetic chemical fertilizers and fungicides, is a major challenge. Despite fungicide treatment for field survey areas of cultivated jujube orchards, several other flowers and fruits have been found to be contaminated with fungal diseases, including gray mold rot, stem rot, and anthracnose (Figure 1c). In Korea, fungal diseases caused by Botrytis cinerea, Botryosphaeria dothidea, and Colletotrichum gloeosporioides are major diseases in jujube fruit. These causative agents are potential fungal pathogens in jujube farms [15-18]. To improve the production of jujube fruit, it is crucial to consider the capacity of beneficial 
microbes on fungal diseases and the production of jujube fruits in cultivated orchards. Therefore, the aim of this study is to observe the biocontrol capacities of fungal plant pathogens such as $B$. cinerea, B. dothidea, and C. gloeosporioides. Another objective of this study was to promote fruit yield in cultivated jujube orchards through the performance of antagonistic bacteria, such as L. antibioticus HS124.

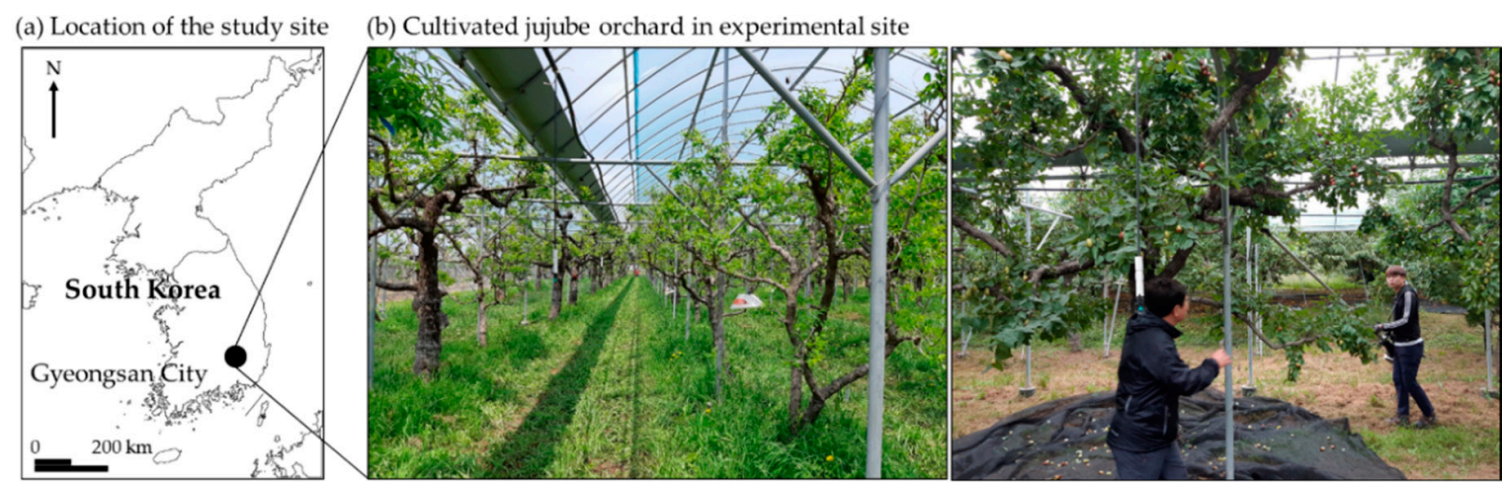

(c) Fungal diseases in jujube fruit

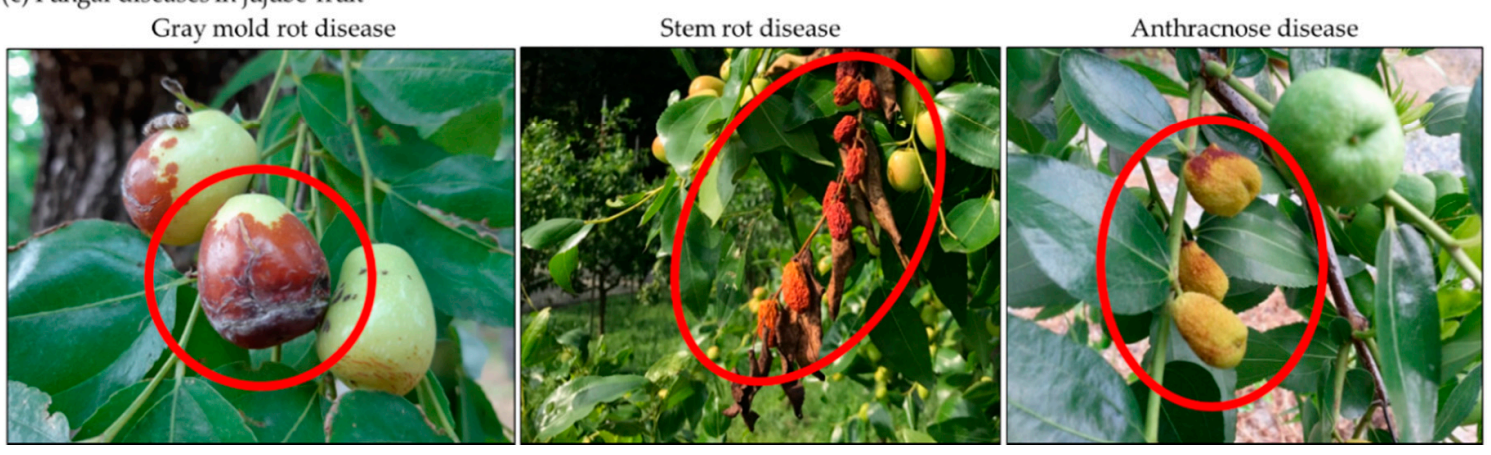

Figure 1. Locations of the study sites (a). Cultivated jujube orchard at the experimental site (b), gray mold rot by B. cinerea (left), stem rot by B. dothidea (center), and anthracnose by C. gloeosporioides (right) (c).

\section{Materials and Methods}

\subsection{Bacterial Culture}

The antagonistic bacterial strain L. antibioticus HS124 was isolated from field rhizosphere soil in Naju City, Korea [30]. It was subcultured in casein-yeast (CY) agar medium (Pancreatic digest of casein (Neogen, Lansing, MI, USA), $3 \mathrm{~g} / \mathrm{L} ; \mathrm{CaCl}_{2} \cdot 2 \mathrm{H}_{2} \mathrm{O}$ (Daejung chemicals, Siheung, Korea), $1.36 \mathrm{~g} / \mathrm{L}$; yeast extract (Daejung chemicals, Siheung, Korea), $1 \mathrm{~g} / \mathrm{L}$; agar (Daejung chemicals, Siheung, Korea), $20 \mathrm{~g} / \mathrm{L}$; and distilled water, $1 \mathrm{~L}$ ). The CY medium composition and preparation for inoculation of L. antibioticus HS124 followed instructions of the Korean Agriculture Culture Collection (KACC, Suwon, Korea). It was incubated at $30{ }^{\circ} \mathrm{C}$ for three days. A single colony from fresh culture medium was pre-inoculated into CY broth (Pancreatic digest of casein, $3 \mathrm{~g} / \mathrm{L} ; \mathrm{CaCl}_{2} \cdot 2 \mathrm{H}_{2} \mathrm{O}, 1.36 \mathrm{~g} / \mathrm{L}$; yeast extract, $1 \mathrm{~g} / \mathrm{L}$; and distilled water, $1 \mathrm{~L}$ ) and cultured for three days. The pre-inoculated broth culture of strain HS124 was also checked with an ultraviolet (UV) spectrometer (Shimadzu, Kyoto, Japan) at $600 \mathrm{~nm}$. Its optical density (OD) value was 1.71 [37]. Then, $100 \mu \mathrm{L}$ of the pre-inoculated L. antibioticus HS124 culture $\left(10^{7} \mathrm{CFU} / \mathrm{mL}\right)$ was inoculated into $100 \mathrm{~mL}$ of $\mathrm{CY}$ broth and incubated at $30^{\circ} \mathrm{C}$ for 10 days with shaking (130 rpm). Samples were collected on each inoculation day and spread onto CY agar medium using the serial dilution technique. The viable bacterial cells were counted as colony forming unit (CFU) on each inoculation day and the growth pattern of L. antibioticus HS124 was examined [30]. 


\subsection{Chitinase Activity}

To examine the chitinase activity based on incubation time, L. antibioticus HS124 was cultured in chitin-potato-dextrose (CPD) broth (Colloidal chitin [38], $10 \%$; yeast extract, $0.05 \%$; and potato dextrose broth (Daejung chemicals, Siheung, Korea), $1.2 \%$ ) at $30{ }^{\circ} \mathrm{C}$ for 10 days in a shaking incubator at $130 \mathrm{rpm}$ [39]. Samples were taken at 2-day intervals and centrifuged at 12,000 rpm for $10 \mathrm{~min}$. The resulting supernatant was used to investigate chitinase activity on each sampling day.

Chitinase activity was measured by the Lingappa and Lockwood method [40]. Briefly, a reaction mixture containing $50 \mu \mathrm{L}$ of L. antibioticus HS124 supernatant, $450 \mu \mathrm{L}$ of $0.2 \mathrm{M}$ sodium acetate buffer ( $\mathrm{pH} 5.0$ ), and $500 \mu \mathrm{L}$ of $0.5 \%$ colloidal chitin was incubated at $37^{\circ} \mathrm{C}$. Subsequently, $200 \mu \mathrm{L}$ of $1 \mathrm{~N}$ $\mathrm{NaOH}$ (Yakuri pure chemicals, Kyoto, Japan) was added to terminate the reaction. The mixture was centrifuged at $12,000 \mathrm{rpm}$ for $10 \mathrm{~min}$ at $4{ }^{\circ} \mathrm{C}$. Next, $750 \mu \mathrm{L}$ of the supernatant was mixed with $1 \mathrm{~mL}$ of Schales' reagent and $250 \mu \mathrm{L}$ of distilled water and incubated at $100{ }^{\circ} \mathrm{C}$ boiling water for $15 \mathrm{~min}$. The amount of reducing sugar was then quantitatively analyzed at $420 \mathrm{~nm}$ using a UV-spectrometer. The assay was repeated three times. One unit of chitinase enzyme activity was determined as the quantity of enzyme releasing $1 \mu \mathrm{mol}$ of $\mathrm{N}$-acetyl-glucosamine per hour at $37^{\circ} \mathrm{C}$.

\subsection{Antifungal Activity of L. antibioticus HS124 toward Fungal Phytopathogens}

The phytopathogenic fungi used in this study, B. cinerea (KACC 41008), B. dothidea (KACC 45481), and C. gloeosporioides (KACC 40897), were provided by the KACC. These three phytopathogenic fungi were cultured in potato dextrose agar (PDA) medium at $25^{\circ} \mathrm{C}$ for seven days. The antagonistic activities of L. antibioticus HS124 against three phytopathogenic fungi were determined by the dual culture method. One-loopful of L. antibioticus HS124 colonies was streaked on one side of a CY agar plate and incubated at $30{ }^{\circ} \mathrm{C}$ for three days [30]. Then, a 5-mm plug of each phytopathogenic fungus from a 7-day-old culture plate was placed on the other side of the same plate at a distance of $4 \mathrm{~cm}$ and the plates were incubated at $25^{\circ} \mathrm{C}$. Depending on the growth rate of each phytopathogenic fungus, the incubation days were different: B. cinerea, four days; B. dothidea, five days; and C. gloeosporioides, eight days. A plate without inoculation of L. antibioticus HS124 was used as a control. The experiment was repeated three times with three replications. The inhibition of fungal growth by the HS124 strain was determined with the following formula: inhibition $(\%)=[(\alpha-\beta) / \alpha] \times 100$, where $\alpha$ was the radial growth of phytopathogenic fungus on the control plate and $\beta$ was the radial growth of phytopathogenic fungus on the dual culture plate $[27,28,30]$.

A small piece of mycelium at the boundary of the fungal colony inhabited by L. antibioticus HS124 was taken and observed for hyphal deformation and degradation caused by L. antibioticus HS124 under a light microscope at 200× magnification (Olympus BX41TF, Tokyo, Japan).

\subsection{Indole-3-Acetic Acid (IAA) Production by L. antibioticus HS124}

Quantitative analyses of IAA production by L. antibioticus HS124 were performed using a UV spectrometric method. Briefly, L. antibioticus HS124 was cultured in a medium containing $0.1 \mathrm{~g} / \mathrm{L}$ crab shell powder (Purne, Jangseong, Korea), $0.2 \mathrm{~g} / \mathrm{L} \mathrm{Na}_{2} \mathrm{HPO}_{4}$ (Daejung chemicals, Siheung, Korea), $0.1 \mathrm{~g} / \mathrm{L} \mathrm{KH}_{2} \mathrm{PO}_{4}$ (Daejung chemicals, Siheung, Korea), $0.5 \mathrm{~g} / \mathrm{L} \mathrm{NaCl}$ (Daejung chemicals, Siheung, Korea), $0.1 \mathrm{~g} / \mathrm{L} \mathrm{NH}_{4} \mathrm{Cl}$ (Yakuri pure chemicals, Kyoto, Japan), $0.05 \mathrm{~g} / \mathrm{L} \mathrm{MgSO}_{4} 7 \mathrm{H}_{2} \mathrm{O}$ (Shimakyu's pure chemicals, Osaka, Japan), $0.05 \mathrm{~g} / \mathrm{L} \mathrm{CaCl}_{2} 2 \mathrm{H}_{2} \mathrm{O}, 0.01 \mathrm{~g} / \mathrm{L}$ yeast extract, and $0.1 \mathrm{~g} / \mathrm{L}$ L-tryptophan (Junsei chemical, Tokyo, Japan). The culture was incubated at $30^{\circ} \mathrm{C}$ in a shaking incubator (140 rpm). Samples were taken every two days five times from the day of inoculation. Quantitative measurement of the HS124 strain was performed according to Salkowski's method [41]. Briefly, the samples were centrifuged at $12,000 \mathrm{rpm}$ for $10 \mathrm{~min}$ at $4{ }^{\circ} \mathrm{C}$ and $1 \mathrm{~mL}$ of the resulting supernatant was mixed with $2 \mathrm{~mL}$ of Salkowski's reagent. Subsequently, the reaction mixture was incubated at room temperature under dark conditions for $25 \mathrm{~min}$. The IAA concentration of each sample was measured at $530 \mathrm{~nm}$ using a UV-spectrometer. 


\subsection{Study Area and Field Experimental Conditions}

The experimental sites of a cultivated jujube orchard were located $\left(35^{\circ} 84^{\prime} 69^{\prime \prime} \mathrm{N}, 128^{\circ} 80^{\prime} 40^{\prime \prime} \mathrm{E}\right)$ in Gyeongsan City, Gyeongbuk Province, Korea (Figure 1a). The soils at the study sites were fluvial deposits. The major soil type of the study area was sandy loam. The experimental sites in Gyeongsan City had a temperate climate with a mean temperature of $14.6{ }^{\circ} \mathrm{C}$ in 2016 . The precipitation on-site was $1227 \mathrm{~mm}$, approximately 57\% of which fell between July 2016 and September 2016.

The jujube trees in the study area were planted in the 1970s (Figure 1b). In 2016, approximately 46-year-old trees with a height of approximately $4 \mathrm{~m}$ and a diameter of approximately $15 \mathrm{~cm}$ were distributed in the study areas. In addition, a rain shelter with transparent vinyl was installed above the tree crown to prevent the fall of fruits because of rain (Figure 1b). Jujube field experiment was arranged using a rectangular plot design measuring $8 \mathrm{~m}$ wide $\times 24 \mathrm{~m}$ long with a distribution of 10 trees (Figure 1b). The following two treatment groups were used in the field experiment, each with three replicates: (1) control without L. antibioticus HS124 inoculation and (2) L. antibioticus HS124 inoculation.

The L. antibioticus HS124 cultures were prepared in CY medium. The liquid form of microbial product containing $10^{10} \mathrm{CFU} / \mathrm{mL}$ of L. antibioticus HS124 (GCM+, Purne, Jangseong, Korea) was used for large scale cultivation of L. antibioticus HS124. Typically, $150 \mathrm{~mL}$ of L. antibioticus HS124 liquid product was inoculated into $500 \mathrm{~L}$ of $\mathrm{CY}$ medium and cultured at $30{ }^{\circ} \mathrm{C}$ for seven days using a fermenter. The L. antibioticus HS124 cultures were diluted with tap water $(1: 2 \mathrm{v} / \mathrm{v})$ and poured onto the soil adjacent to the tree roots at approximately 2-week intervals 14 times from April to September 2016.

\subsection{Mineral Concentration, Fruit Characteristics, and Yield}

To determine the fruit characteristics (length and diameter) and fruit yield after treatments, six jujube trees in each plot were selected and the fruits of branches with a similar length and height and facing south compared to a standard were harvested in October 2016. The weight of fresh fruit from a standard branch in each sample tree was recorded to determine the yield. In addition, fruit length and diameter were calculated with respect to 10 fruit in each sample tree.

Undamaged jujube fruits were selected and washed thoroughly with distilled water to remove dirt and air-dried. The fruit was finely chopped into small pieces using a sharp knife and the seeds were separated from the pulp. The prepared sample was pretreated using a dry decomposition method [42]. For dry decomposition, $0.7 \mathrm{~g}$ of the sample was ashed at $550{ }^{\circ} \mathrm{C}$, then $10 \mathrm{~mL}$ of a diluted solution ( $\mathrm{HCl}$ :distilled water $=1: 1$ ) was added to the ash, followed by decomposition at $25^{\circ} \mathrm{C}$ for six hours. Thereafter, a funnel was inserted into a 50 -mL volumetric flask, the ash solution was filtered through filter paper, massed with distilled water, and used as a test solution. The mineral compositions were determined using a procedure described by the AOAC (Association of Official Analytical Chemists) [42]. Each mineral (potassium $(\mathrm{K})$, calcium $(\mathrm{Ca})$, magnesium $(\mathrm{Mg})$, and phosphorus $(\mathrm{P})$ ) was detected with an inductively coupled plasma optical emission spectrometer (PerkinElmer, Waltham, MA, USA).

\subsection{Statistical Analysis}

All statistical calculations were performed using the Statistical Package for the Social Sciences (SPSS) software, version 23 (Armonk, New York, NY, USA). The results are reported as the mean \pm standard deviation. The data were evaluated by $t$-tests with significance considered at $p<0.05$.

\section{Results}

\subsection{Inhibitory Effect of L. antibioticus HS124 on Growth of Fungal Pathogens}

\subsubsection{Chitinase Activity}

The growth of L. antibioticus HS124 was low until five days post-inoculation (Figure 2) and exhibited a rapid increase six days post-inoculation. The maximum growth $\left(5.67 \times 10^{7} \mathrm{CFU} / \mathrm{mL}\right)$ was 
found seven days post-inoculation. Subsequently, the growth moderately decreased until the end of the inoculation period (Figure 2).

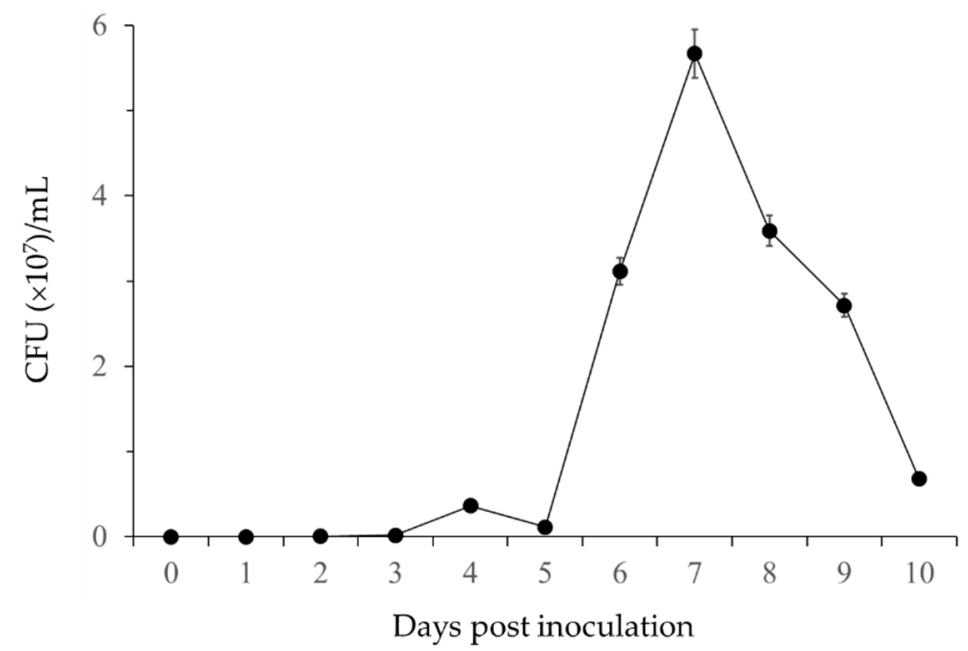

Figure 2. Cell growth curve of L. antibioticus HS124 in CY medium at $30{ }^{\circ} \mathrm{C}$ for 10 days. Error bars represent the standard deviation of three replications. CFU: colony forming unit.

The chitinase activity of L. antibioticus HS124 increased after two days and eventually reached a maximum value of $81.1 \mathrm{unit} / \mathrm{mL}$ over a period of four days (Figure 3). Thereafter, chitinase activity remained steady until eight days post-inoculation (Figure 3).

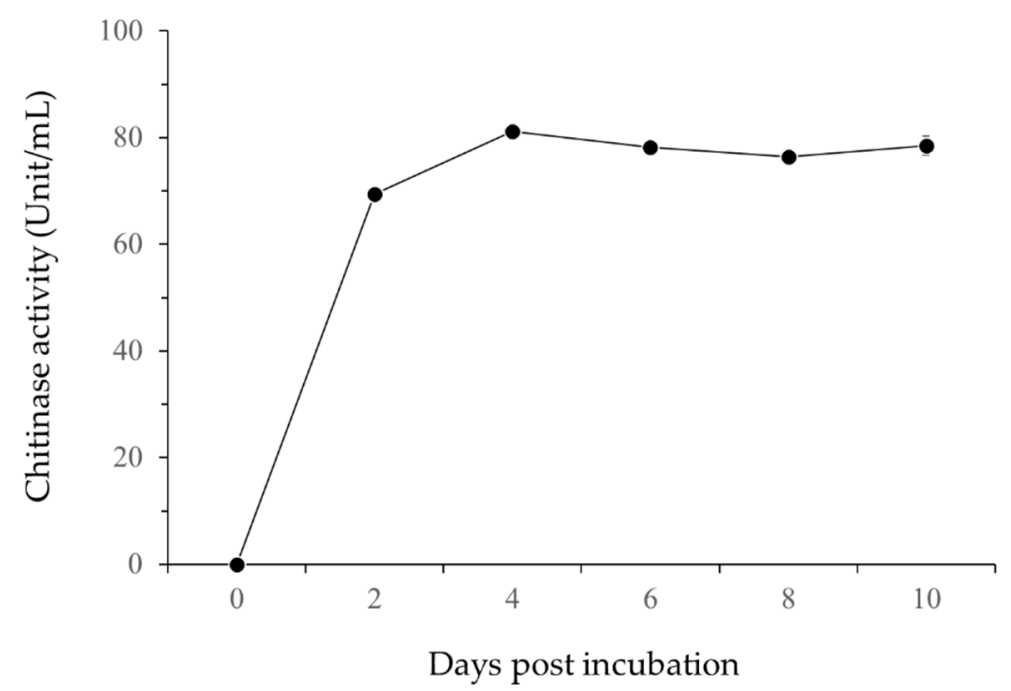

Figure 3. Chitinase activity of L. antibioticus HS124 cultured in CPD broth at $30{ }^{\circ} \mathrm{C}$ for 10 days. Quantitative measurement of chitinase enzymes produced by strain HS124 was done using a UV-spectrophotometer at $420 \mathrm{~nm}$.

\subsubsection{Growth Inhibition of Phytopathogenic Fungi by L. antibioticus HS124}

The antifungal activities of L. antibioticus HS124 against different phytopathogenic fungi, including B. cinerea, B. dothidea, and C. gloeosporioides, were assayed in CY agar medium using the dual culture test (Figure 4). L. antibioticus HS124 showed the highest inhibition (27.25\%) against B. dothidea and the lowest inhibition (20.56\%) against C. gloeosporioides (Figure 4). Moreover, it showed $22.03 \%$ mycelial growth inhibition against $B$. cinerea (Figure 4 ).

The hyphal morphologies by L. antibioticus HS124 were abnormal, showing degradation, deformation, and lysis, compared to controls not inoculated with L. antibioticus HS124. The controls showed normal hyphal structures (Figure 5). 
(a) Growth inhibition of pathogens

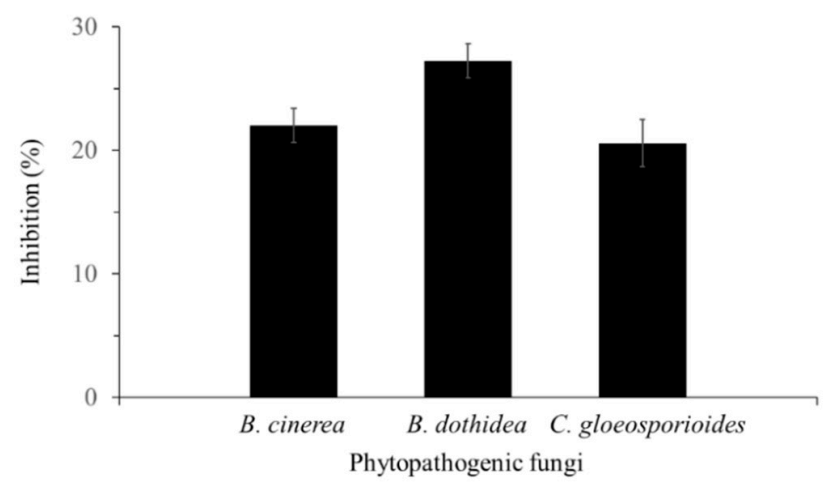

(b) Antagonistic activity

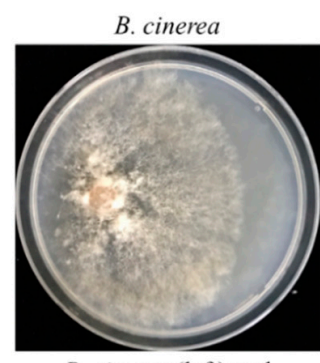

B. cinerea (left) and L. antibioticus $\mathrm{HS} 124$ (right)

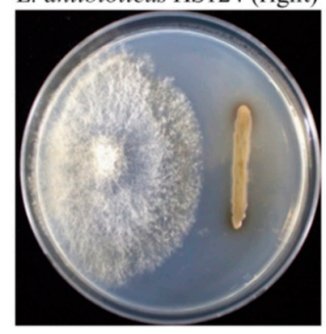

B. dothidea

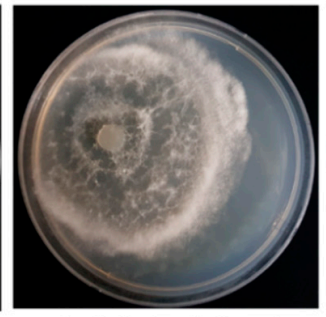

B. dothidea (left) and L. antibioticus HS124 (right)

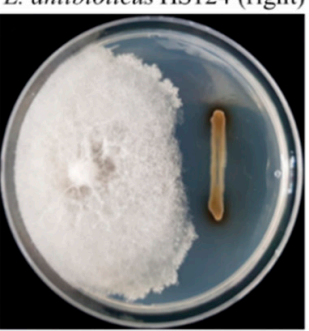

C. gloeosporioides

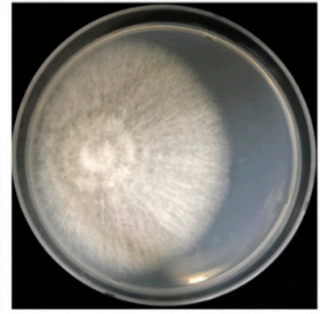

C. gloeosporioides (left) and L. antibioticus HS124 (right)

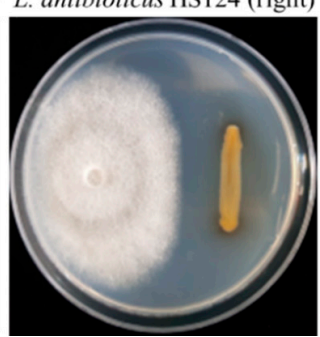

Figure 4. Inhibitory effect of $L$. antibioticus HS124 on mycelial growth of B. cinerea, B. dothidea, and C. gloeosporioides (a), and antagonistic activity of L. antibioticus HS124 against fungal pathogens (b) by the dual culture method.

(a) Control (B. cinerea)

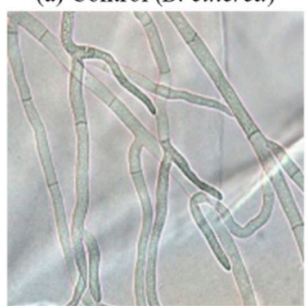

(d) L. antibioticus HS124 treatment

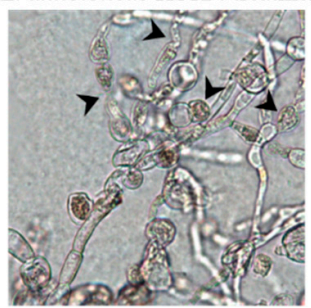

(b) Control (B. dothidea)

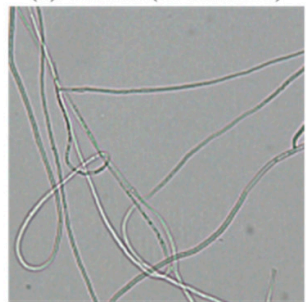

(e) L. antibioticus HS124 treatment (f) L. antibioticus HS124 treatment

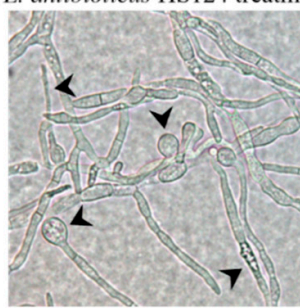

(c) Control (C. gloeosporioides)
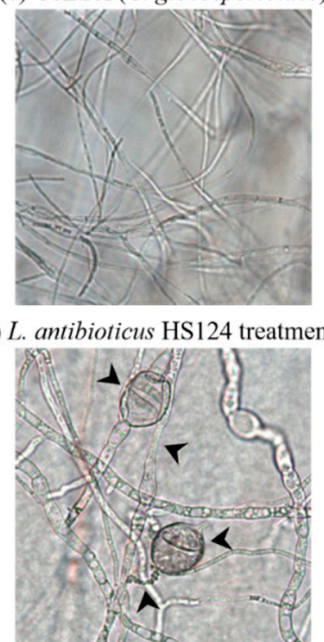

Figure 5. Deformed hyphal morphologies of B. cinerea (d); B. dothidea (e); and C. gloeosporioides (f) affected by L. antibioticus HS124 compared to B. cinerea control (a); B. dothidea control (b); and C. gloeosporioides control (c) under a light microscope. Arrows indicate hyphal alterations with swelling and bulbous structures caused by L. antibioticus HS124. 


\subsection{Effect of L. antibioticus HS124 on Fruit Yield}

\subsubsection{IAA Production}

L. antibioticus HS124 produced auxin (Figure 6). The IAA concentration steadily increased for six days, eventually reaching a maximum value of $9.3 \mathrm{mg} / \mathrm{L}$. Thereafter, the IAA concentration decreased rapidly (Figure 6).

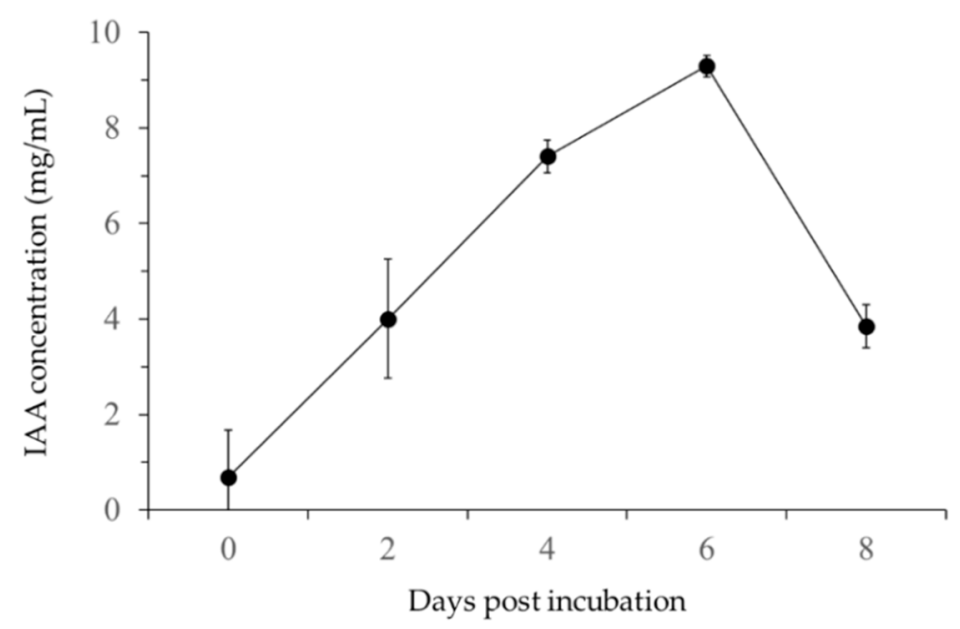

Figure 6. IAA (indole-3-acetic acid) production by L. antibioticus HS124.

\subsubsection{Mineral Concentration, Characteristics, and Yield of Jujube Fruits}

Potassium (K) was the most abundant mineral $(2.12 \mathrm{~g} / \mathrm{kg})$ in the fruit, followed by P $(0.21 \mathrm{~g} / \mathrm{kg})$ (Table 1). The fruit contained relatively low concentrations of $\mathrm{Ca}$ and $\mathrm{Mg}$. A significant increase in the concentrations of $\mathrm{K}, \mathrm{Ca}, \mathrm{Mg}$, and $\mathrm{P}$ was observed in the jujube fruits inoculated with L. antibioticus HS124 when compared to that of the control group (Table 1). The $\mathrm{K}$ and $\mathrm{Mg}$ concentrations in fruits with bacterial inoculation were 1.8- and 2.0-fold more than that of control group, respectively (Table 1). Moreover, the $\mathrm{P}$ and $\mathrm{Ca}$ concentrations in fruits that were inoculated with bacteria were 1.4- and 1.6-fold more than that of control group, respectively (Table 1).

Table 1. Mineral concentration, characteristics, and yields of jujube fruits in control and treatment groups with L. antibioticus HS124 inoculation in cultivated orchards.

\begin{tabular}{|c|c|c|c|c|c|c|c|}
\hline Treatment & \multicolumn{4}{|c|}{ Fruit Mineral (g/kg) } & \multicolumn{2}{|c|}{ Fruit Characteristics (mm) } & Fruit Yield (g) \\
\hline Control & $1.18 \pm 0.18 *$ & $0.05 \pm 0.01 *$ & $0.04 \pm 0.01 *$ & $0.15 \pm 0.02 *$ & $29.66 \pm 1.67$ * & $23.77 \pm 1.24 *$ & $2165.78 \pm 221.19$ * \\
\hline $\begin{array}{c}\text { Bacterial } \\
\text { inoculation }\end{array}$ & $2.12 \pm 0.17 *$ & $0.08 \pm 0.01 *$ & $0.08 \pm 0.01 *$ & $0.21 \pm 0.03 *$ & $38.37 \pm 1.41 *$ & $28.99 \pm 1.53 *$ & $6284.67 \pm 1207.23$ * \\
\hline
\end{tabular}

The length of the jujube fruits ranged from 35.39 to $40.85 \mathrm{~mm}$ with L. antibioticus HS124 inoculation and from 26.93 to $33.70 \mathrm{~mm}$ in the control without L. antibioticus HS124 inoculation (Table 1). The length of the fruits inoculated with bacteria was significantly higher than that of the control (Table 1). The average diameter of the jujube fruits ranged from $23.77 \mathrm{~mm}$ in the control to $28.99 \mathrm{~mm}$ with bacterial inoculation (Table 1). Regarding fruit characteristics of jujube cultivated in the orchard, the length and diameter of fruits inoculated with bacteria were significantly higher than those of the control fruits (Table 1).

The average yield of jujube fruit ranged from $2165.78 \mathrm{~g} / \mathrm{branch}$ in the control to $6284.67 \mathrm{~g} / \mathrm{branch}$ in trees inoculated with L. antibioticus HS124 (Table 1). A remarkable improvement in fruit yield was observed in treatment with L. antibioticus HS124 as compared to that of control (Table 1). 


\section{Discussion}

Cell wall-degrading enzymes such as chitinase produced by antagonistic bacteria are known to play key roles in the suppression of phytopathogenic fungi [25-30]. In the present study, results of quantitative chitinase assay indicated that strain HS124 produced high levels of chitinase in colloidal containing medium (Figure 3). Therefore, the action of chitinase could be involved in antagonism against these fungal pathogens, including B. cinerea, B. dothidea, and C. gloeosporioides (Figures 4 and 5). In the presence of L. antibioticus HS124, the hyphae of phytopathogenic fungi showed abnormal morphologies, including swelling and bulb formation (Figure 5). Our results are in agreement with previous report of Won et al. $[27,28]$, showing that chitinase enzymes produced by Bacillus licheniformis MH48 were involved in the control of diseases caused by fungi such as Fusarium oxysporum, B. cinerea, Glomerella cingulate, Pestalotia diospyri, and Pestalotiopsis karstenii. In a similar experiment, Brzezinska and Jankiewicz [43] showed that a chitinase secreted by Aspergillus niger LOCK62 had antifungal activities against various other fungi such as Fusarium solani, Fusaium culmorum, and B. cinerea. According to Velusamy and Kim [44], a chitinase secreted by Enterobacter sp. could decompose mycelia of C. gloeosporioides and B. cinerea and inhibit their growth. The antagonistic activity of L. antibioticus HS124 against phytopathogenic fungi resulted in a significant increase in the production of jujube fruits in cultivated orchards (a 2.9-fold increase) compared to the control (Table 1). Control jujube fruit and trees were easily infected by fungal diseases (Figure 1c), resulting in wilting and dropping of fruit during production. Fungal pathogen-infected fruits were discarded during harvesting (Figure 1b), thus decreasing the fruit production (Table 1). In particular, our field observations frequently found anthracnose disease which led to a reduction in the production of jujube fruit because of the increased flower wilting and fruit dropping. In addition, L. antibioticus HS124 produced auxin (Figure 6). Auxin acts at the time of cell division after fertilization of flowers [31,33,34], thus increasing the size of the fruit and improving the yield of trees inoculated with L. antibioticus HS124 (Table 1). PGPR also provides nutrients to the soil by fixing nitrogen from the atmosphere and solubilizing phosphorus in the soil $[26,45]$. Plants with increased absorption of nitrogen and phosphorus can promote photosynthesis and protein biosynthesis, thus increasing the size and yield of the fruit [46-49]. In cultivated orchard experiments, the size and yield of jujube fruits from trees inoculated with L. antibioticus HS124 were significantly increased (Table 1).

Well development in root system of trees are the most essential attribute for enhancing minerals and nutrient uptake $[25,27,28,49]$. Auxin produced by L. antibioticus HS124 inoculation might promote root development and stimulate the formation of absorbent root hairs and lateral roots $[24,25,27,28,31,32]$. This finding indicates that jujube trees inoculated with L. antibioticus HS124 could absorb more mineral elements such as $\mathrm{K}, \mathrm{Ca}, \mathrm{Mg}$, and P in fruits (Table 1). Because PGPR including Lysobacter sp. can secrete organic acids and mineralize mineral elements such as $\mathrm{K}, \mathrm{Ca}, \mathrm{Mg}, \mathrm{Fe}$, and $\mathrm{P}$ from soil and enrich them in the soil $[26,45,47,49]$, roots developed by auxin can promote the absorption of minerals and nutrient elements $[24,25,27,32,48,50]$. In addition, the photosynthesis of plants in the nitrogen-enhanced soils caused by nitrogen fixation from PGPR is enhanced, resulting in increased growth and mineral absorption in plants [26,45,48-52]. According to Ipek et al. [45] and Pirlak et al. [51] apples and strawberries with PGPR such as Pseudomonas sp., Bacillus sp., Alcaligenes sp., Staphylococcus sp., and Agrobacterium sp. can promote the photosynthesis caused by nitrogen fixation and stimulate the growth and contents of mineral elements. Results of the present study indicate that L. antibioticus HS124 is not only an effective biocontrol agent for phytopathogenic fungi, but also a beneficial agent for increasing the fruit mineral content and yield in jujube farms.

\section{Conclusions}

L. antibioticus HS124 could suppress fungal diseases caused by B. cinerea, B. dothidea, and C. gloeosporioides by producing lytic enzymes, including chitinase (Figures 3-5), thereby decreasing the fruit wilting and dropping during the production and harvest periods of cultivated jujube orchards (Figure 1c). The improvement in size and yield of jujube fruits in the present study could be associated 
with the secretion of auxin like IAA by L. antibioticus HS124 (Table 1). Therefore, inoculating L. antibioticus HS124 to jujube trees should be considered as a potential way to control fungal diseases and increase the production of jujube fruits in a sustainable and ecological cultivation system of orchards.

Author Contributions: Conceptualization, funding acquisition and project administration, Y.-S.A.; investigation and experiments, J.-H.K., S.-J.W., and J.-H.M.; data analysis, J.-H.K. and S.-J.W.; resources, C.-W.K.; writing-original draft preparation, J.-H.K.; writing—review and editing, Y.-S.A.

Funding: This study was supported by the R\&D program for Forest Science \& Technology Projects (No. 2018122B10-1820-AB01) funded by the Korea Forest Service (Korea Forestry Promotion Institute). Additionally, this research was supported by a grant (No. 2018R1D1A1B07050052) of the National Research Foundation (NRF) of Korea under the Basic Science Research Program.

Acknowledgments: The authors would like to thank Kil-Yong Kim at the Chonnam National University for the technical assistance in the field and laboratory. The senior author also thanks Yun-Serk Park, CEO of Purne for their skillful assistance in analyzing the bacteria.

Conflicts of Interest: The authors declare no conflicts of interest.

\section{References}

1. Pareek, S. Nutritional composition of jujube fruit. Emir. J. Food Agric. 2013, 25, 463-470. [CrossRef]

2. Liu, M.J.; Cheng, C.Y. A taxonomic study on the genus Ziziphus. Acta Hortic. 1995, 390, 161-165. [CrossRef]

3. Hernández, F.; Legua, P.; Melgarejo, P.; Martinez, R.; Martinez, J.J. Phenological growth stages of jujube tree (Ziziphus jujube): Codification and description according to the BBCH scale. Ann. Appl. Biol. 2015, 166, 136-142. [CrossRef]

4. Krša, B.; Mishra, S. Sensory evaluation of different products of Ziziphus jujuba Mill. Acta Hortic. 2009, 840, 557-562. [CrossRef]

5. Gao, Q.H.; Wu, C.S.; Wang, M.; Xu, B.N.; Du, L.J. Effect of drying of jujubes (Ziziphus jujuba Mill.) on the contents of sugars, organic acids, $\alpha$-tocopherol, $\beta$-carotene, and phenolic compounds. J. Agric. Food Chem. 2012, 60, 9642-9648. [CrossRef]

6. Wojdyło, A.; Ángel, A.C.B.; Legua, P.; Hernández, F. Phenolic composition, ascorbic acid content, and antioxidant capacity of Spanish jujube (Ziziphus jujube Mill.) fruit. Food Chem. 2016, 201, 307-314. [CrossRef]

7. Shahrajabian, M.H.; Khoshkharam, M.; Zandi, P.; Sun, W.; Cheng, Q. Jujube, a super-fruit in traditional Chinese medicine, heading for modern pharmacological science. J. Med. Plants Stud. 2019, 7, 173-178.

8. Godbole, S. Overview of traditional knowledge and scientific research on medicinal uses of leaves and flowers offered during festivals. World J. Pharmaceut. Res. 2018, 7, 523-546. [CrossRef]

9. Goyal, M.; Nagori, B.P.; Sasmal, D. Review on ethnomedicinal uses, pharmacological activity and phytochemical constituents of Ziziphus mauritiana (Z. jujube Lam., non Mill). Spatula DD 2012, 2, 107-116. [CrossRef]

10. Marrelli, M.; Conforti, F.; Araniti, F.; Statti, G.A. Effects of saponins on lipid metabolism: A review of potential health benefits in the treatment of obesity. Molecules 2016, 21, 1404. [CrossRef]

11. Hernández, F.; Luis, N.A.; Burló, F.; Wojdyło, A.; Ángel, A.C.B.; Legua, P. Physico-chemical, nutritional, and volatile composition and sensory profile of Spanish jujube (Ziziphus jujube Mill.) fruits. J. Sci. Food Agric. 2016, 96, 2682-2691. [CrossRef] [PubMed]

12. Guo, S.; Duan, J.A.; Tang, Y.; Su, S.; Shang, E.; Ni, S.; Qian, D. High-performance liquid chromatography-wo wavelength detection of triterpenoid acids from the fruits of Ziziphus jujuba containing various cultivars in different regions and classification using chemometric analysis. J. Pharmaceut. Biomed. 2009, 49, 1296-1302. [CrossRef] [PubMed]

13. Zhang, H.; Jiang, L.; Ye, S.; Ye, Y.; Ren, F. Systematic evaluation of antioxidant capacities of the ethanolic extract of different tissues of jujube (Ziziphus jujube Mill.) from China. Food Chem. Toxicol. 2010, 48, 1461-1465. [CrossRef] [PubMed]

14. Morton, J.F. Fruits of Warm Climates; Purdue University: Miami, FL, USA, 1987; pp. 272-275.

15. Williamson, B.; Tudzynski, B.; Tudzynski, P.; Kan, J.A.L.V. Botrytis cinerea: The cause of grey mould disease. Mol. Plant Pathol. 2007, 8, 561-580. [CrossRef] [PubMed] 
16. Phoulivong, S.; Cai, L.; Chen, H.; McKenzie, E.H.C.; Abdelsalam, K.; Chukeatirote, E.; Hyde, K.D. Colletotrichum gloeosporioides is not a common pathogen on tropical fruits. Fungal Divers. 2010, 44, $33-43$. [CrossRef]

17. Zhu, H.Y.; Tian, C.M.; Fan, X.L. Studies of botryosphaerialean fungi associated with canker and dieback of tree hosts in Dongling Mountain of China. Phytotaxa 2018, 348, 63-76. [CrossRef]

18. He, C.; Zhang, Z.; Li, B.; Xu, Y.; Tian, S. Effect of natamycin on Botrytis cinerea and Penicillium expansum-Postharvest pathogens of grape berries and jujube fruit. Postharvest Biol. Technol. 2019, 151, 134-141. [CrossRef]

19. O'connell, P.F. Sustainable agriculture-A valid alternative. Outlook Agric. 1992, 21, 5-12. [CrossRef]

20. Gisi, U.; Sierotzki, H.; Cook, A.; McCaffery, A. Mechanisms influencing the evolution of resistance to Qo inhibitor fungicides. Pest Manag. Sci. 2002, 58, 859-867. [CrossRef]

21. Savci, S. An agricultural pollutant: Chemical fertilizer. Int. J. Environ. Sci. Dev. 2012, 3, 77-80. [CrossRef]

22. Juntunen, M.L.; Hammar, T.; Rikala, R. Leaching of nitrogen and phosphorus during production of forest seedlings in containers. J. Environ. Qual. 2002, 31, 1868-1874. [CrossRef] [PubMed]

23. Youssef, M.M.A.; Eissa, M.F.M. Biofertilizers and their role in management of plant parasitic nematodes. A review. E3 J. Biotechnol. Pharm. Res. 2014, 5, 1-6.

24. Glick, B.R.; Penrose, D.M.; Li, J. A Model for the lowering of plant ethylene concentrations by plant growth-promoting bacteria. J. Theor. Biol. 1998, 190, 63-68. [CrossRef] [PubMed]

25. Glick, B.R. Plant growth-promoting bacteria: Mechanisms and applications. Scientifica 2012, $2012,963401$. [CrossRef] [PubMed]

26. Orhan, E.; Esitken, A.; Ercisli, S.; Turan, M.; Sahin, F. Effects of plant growth promoting rhizobacteria (PGPR) on yield, growth and nutrient contents in organically growing raspberry. Sci. Hortic. 2006, 111, 38-43. [CrossRef]

27. Won, S.-J.; Choub, V.; Kwon, J.-H.; Kim, D.-H.; Ahn, Y.-S. The control of fusarium root rot and development of coastal pine (Pinus thunbergii Parl.) seedlings in a container nursery by use of Bacillus licheniformis MH48. Forests 2019, 10, 6. [CrossRef]

28. Won, S.-J.; Kwon, J.-H.; Kim, D.-H.; Ahn, Y.-S. The effect of Bacillus licheniformis MH48 on control of foliar fungal diseases and growth promotion of Camellia oleifera seedling in the coastal reclaimed land of Korea. Patohgens 2019, 8, 6. [CrossRef]

29. Glick, B.R. The enhancement of plant growth by free-living bacteria. Can. J. Microbiol. 1995, 41, $109-117$. [CrossRef]

30. Ko, H.-S.; Jin, R.-D.; Krishnan, H.B.; Lee, S.-B.; Kim, K.-Y. Biocontrol ability of Lysobacter antibioticus HS124 against Phytophthora blight is mediated by the production of 4-Hydroxyphenylacetic acid and several lytic enzymes. Curr. Microbiol. 2009, 59, 608-615. [CrossRef]

31. Gravel, V.; Antoun, H.; Tweddell, R.J. Growth stimulation and fruit yield improvement of greenhouse tomato plants by inoculation with Pseudomonas putida or Trichoderma atroviride: Possible role of indole acetic acid (IAA). Soil Biol. Biolchem. 2007, 39, 1968-1977. [CrossRef]

32. Goswami, D.; Thakker, J.N.; Dhandhukia, P.C. Portraying mechanics of plant growth promoting rhizobacteria (PGPR): A review. Cogent Food Agric. 2016, 2. [CrossRef]

33. Srivastava, A.; Handa, A.K. Hormonal regulation of tomato fruit development: A molecular perspective. J. Plant Growth Regul. 2005, 24, 67-82. [CrossRef]

34. Liu, D.J.; Chen, J.Y.; Lu, W.J. Expression and regulation of the early auxin-responsive $A u x / I A A$ genes during strawberry fruit development. Mol. Biol. Rep. 2011, 38, 1187-1193. [CrossRef] [PubMed]

35. Han, T.; Cho, M.-Y.; Lee, Y.-S.; Park, Y.-S.; Park, R.-D.; Nam, Y.; Kim, K.-Y. Biocontrol of pepper diseases by Lysobacter enzymogenes LE429 and Neem Oil. Korean J. Soil Sci. Fert. 2010, 43, 490-497.

36. Esitken, A.; Ercisli, S.; Karlidag, H.; Sahin, F. Potential use of plant growth promoting rhizobacteria (PGPR) in organic apricot production. In Proceedings of the International Scientific Conference, Polli, Estonia, 7-9 September 2005; Libek, A., Kaufmane, E., Sasnauskas, A., Eds.; Tartu University Press: Tartu, Estonia, 2005; pp. 90-97.

37. Widdel, F. Theory and measurement of bacterial growth. Grund. Mikrobiol. 2007, 4, 1-11.

38. Berger, L.R.; Reynolds, D.M. The chitinase system of a strain of Streptomyces griseus. Biochim. Biophys. Acta 1958, 29, 522-534. [CrossRef] 
39. Kim, Y.-T.; Monkhung, S.; Lee, Y.S.; Kim, K.Y. Effects of Lysobacter antibioticus HS124, an effective biocontrol agent against Fusarium graminearum, on crown rot disease and growth promotion of wheat. Can. J. Microbiol. 2019, 65, 904-912. [CrossRef]

40. Lingappa, Y.; Lockwood, J. Chitin media for selective isolation and culture of Actinomycetes. Phytopathology 1962, 52, 317-323.

41. Rahman, A.; Sitepu, I.R.; Tang, S.Y.; Hashidoko, Y. Salkowski's reagent test as a primary screening index for functionalities of rhizobacteria isolated from wild dipterocarp saplings growing naturally on medium-strongly acidic tropical peat soil. Biosci. Biotechnol. Biochem. 2010, 74, 2202-2208. [CrossRef]

42. Association of Analytical Communities. Official Methods of Analysis of the Association of Official Analytical Chemists, 15th ed.; Helich, K., Ed.; Association of Official Analytical Chemists, Inc.: Arlington, VA, USA, 1990; Volume 1, pp. 40-58.

43. Brzezinska, M.S.; Jankiewicz, U. Production of antifungal chitinase by Aspergillus niger LOCK 62 and its potential role in the biological control. Curr. Microbiol. 2012, 65, 666-672. [CrossRef]

44. Velusamy, P.; Kim, K.Y. Chitinolytic activity of Enterobacter sp. KB3 antagonistic to Rhizoctonia solani and its role in the degradation of living fungal hyphae. Int. Res. J. Microbiol. 2011, 2, 206-214.

45. Ipek, M.; Pirlak, L.; Esitken, A.; Donmez, M.F.; Turan, M.; Sahin, F. Plant growth-promoting rhizobacteria (PGPR) increase yield, growth and nutrition of strawberry under high-calcareous soil conditions. J. Plant Nutr. 2014, 37, 990-1001. [CrossRef]

46. Brewster, J.L. Onions and other vegetable alliums. Sci. Hortic. 1994, 62, 145-149. [CrossRef]

47. Osman, A.G.; Elaziz, F.I.A.; Elhassan, G.A. Effects of biological and mineral fertilization on yield, chemical composition and physical characteristics of faba bean (Vicia faba L.) cultivar seleim. Pak. J. Nutr. 2010, 9, 703-708. [CrossRef]

48. Rizk, F.A.; Shaheen, A.M.; Elsamad, E.H.A.; Sawan, O.M. Effect of different nitrogen plus phosphorus and Sulphur fertilizer levels on growth, yield and quality of onion (Allium cepa L.). J. Appl. Sci. Res. 2012, 8, 3353-3361.

49. Raklami, A.; Bechtaoul, N.; Tahiri, A.; Anli, M.; Meddich, A.; Oufdou, K. Use of rhizobacteria and mycorrhizae consortium in the open field as a strategy for improving crop nutrition, productivity and soil fertility. Front. Microbiol. 2019, 10, 1106. [CrossRef]

50. Yolcu, H.; Gunes, A.; Gullap, M.K.; Cakmakci, R. Effects of plant growth-promoting rhizobacteria on some morphologic characteristics, yield and quality contents of Hungarian vetch. Turk. J. Field Crop. 2012, 17, 208-214.

51. Pirlak, L.; Turan, M.; Sahin, F.; Esitken, A. Floral and foliar application of plant growth promoting rhizobacteria (PGPR) to apples increase yield, growth, and nutrient element contents of leaves. J. Sustain. Agric. 2007, 30, 145-155. [CrossRef]

52. Park, H.-G.; Lee, Y.-S.; Kim, K.-Y.; Park, Y.-S.; Park, K.-H.; Han, T.-H.; Park, C.-M.; Ahn, Y.S. Inoculation with Bacillus licheniformis MH48 promotes nutrient uptake in seedling of the ornamental plant Camellia japonica grown in Korea reclaimed coastal lands. Hortic. Sci. Technol. 2017, 35, 11-20. [CrossRef]

(C) 2019 by the authors. Licensee MDPI, Basel, Switzerland. This article is an open access article distributed under the terms and conditions of the Creative Commons Attribution (CC BY) license (http://creativecommons.org/licenses/by/4.0/). 